\title{
Análise do Splicing Alternativo do Gene Hint-1 Através do Código BCH Associado
}

\author{
Luiz Antônio Leandro Franco* Reginaldo Palazzo Júnior ${ }^{\dagger}$ \\ Faculdade de Engenharia Elétrica e de Computação, FEEC, UNICAMP, \\ 13083-859, Campinas, SP \\ E-mail: franco_luiz9@hotmail.com, palazzo@dt.fee.unicamp.br,
}

\section{RESUMO}

Cada célula no corpo humano deve crescer, reproduzir-se, processar informações, responder a estímulos e realizar uma série considerável de reações químicas. As células são envolvidas pela membrana celular e preenchidas com uma solução aquosa concentrada de substâncias químicas, substâncias físicas e o citoplasma. O citoplasma é o material celular localizado entre a membrana celular e o núcleo, sendo o local onde se concentra o maior número de atividades celulares, [1].

Uma molécula de ácido desoxirribonucleico (DNA) consiste de duas longas cadeias polipeptídicas compostas por quatro tipos de subunidades nucleotídicas. No caso dos nucleotídeos do DNA, o açúcar é uma desoxirribose ligada a um único grupo fosfato, cujas bases são: adenina (A), citosina (C), guanina (G) ou timina ( $\mathrm{T}$ ). As sequências codificantes de genes eucarióticos são caracteristicamente interrompidas por sequências intervenientes não-codificantes (íntrons). Tanto as sequências de íntrons quanto de éxons são transcritas em RNA. As sequências dos íntrons são removidas do RNA transcrito por meio de um processo denominado splicing de RNA. Grande parte do splicing de RNA que ocorre nas células atua na produção de mRNA, sendo denominado splicing do precursor de mRNA (ou pré-mRNA). Somente após ter ocorrido o splicing e o processamento das extremidades 5' e 3' esse RNA será denominado mRNA, [2].

O gene Hint-1 do nematoide C. elegans (identificado por "geneID"número 184760, no NCBI) é composto por 3 éxons e 2 íntrons com os seguintes comprimentos (em termos de nucleotídeos): éxon 1 com 123, íntron 1 com 44, éxon 2 com 138, íntron 2 com 74 e éxon 3 com 132, totalizando 511 nucleotídeos. Este gene foi identificado como uma palavra-código de um código $\mathrm{BCH}$ com parâmetros $(511,502,3)$ sobre o anel $\mathbb{Z}_{4}$ com polinômio gerador $g(x)=x^{9}+2 x^{7}+x^{5}+3$, via o algoritmo de geração de sequências de DNA proposto em [3]-[5]. A matriz geradora $G$ tem dimensão $502 \times 511$. Por outro lado, sabemos do processo de codificação que a palavra-código $\mathbf{v}$ (sequência do gene Hint-1) resulta da seguinte operação $\mathbf{v}=\mathbf{u} . G$. Desse processo temos duas possibilidades de análise. A primeira tem a ver com a caracterização das submatrizes associadas aos correspondentes éxons e íntrons do gene Hint-1 e suas relações. A segunda tem a ver com as componentes do vetor $\mathbf{u}$, que chamaremos vetor de sinalização.

Sob o ponto de vista do vetor sinalização, notamos que existem componentes deste vetor que são comuns tanto a éxons como a íntrons, mostrando uma forte ligação na região de fronteira. Uma intrepretação biológica que fazemos do vetor sinalização u é a de realizar a localização/identificação no DNA da sequência precursora do RNA, pré-RNA. O próximo passo é a obtenção do mRNA associado ao correspondente gene. Para isso, é necessário que o mecanismo de splicing do pré-mRNA entre em ação. Isto por sua vez implica que a maquinaria de splicing deve reconhecer três regiões na molécula precursora

\footnotetext{
*Bolsista de Mestrado - CAPES

${ }^{\dagger}$ Pesquisa com suporte financeiro do CNPq e FAPESP
} 
do RNA: a região de splicing 5', a região de splicing 3' e o ponto da forquilha na sequência do íntron que forma a base do fragmento em laço a ser excisado. Cada um desses três sítios tem uma sequência nucleotídica consenso, que é similar entre os íntrons e que fornece a posição onde deve ocorrer o splicing.

Sob o ponto de vista da matriz geradora $G$, o espaço vetorial gerado tem dimensão 502. Todavia, as dimensões dos subespaços correspondentes aos éxon 1, íntron 1, éxon 2, íntron 2, e éxon 3 apresentam os seguintes valores $123,53,147,83,132$. Note que a soma dessas dimensões vale 538, portanto ultrapassando o valor 502. Isso implica que o espaço total não é uma soma direta dos correspondentes subespaços. Mais ainda, estabelece uma dependência entre os subespaços vizinhos. Essa dependência entre subespaços vizinhos nada mais é que uma memória associada. Biologicamente podemos inferir que um íntron estabelece um processo de "amarramento"entre os éxons subsequentes e que se mostram importantes tanto no aspecto da realização do splicing alternativo como no da confiabilidade. Ambos processos de vital importância para a conservação da espécie.

A quantidade de proteínas decorrentes do realização do processo de splicing alternativo do gene Hint-1, as isoformas e suas relações bem como as análises de "inserção"e "deleção"de núcleotídeos nos limiares dos pares éxon-íntron e íntron-éxon serão apresentadas tendo como base a utilização dos códigos de Tenengolts, [6].

Palavras-chave: Códigos Corretores de Erros, Splicing Alternativo e Hint-1

\section{Referências}

[1] Marieb E. N., Hoehn K., Anatomia e Fisiologia, Artmed, 2009.

[2] Bruce Alberts et al., Biologia Molecular da Célula, 5th Edition, Artmed, 2010.

[3] Rocha ASL, Faria LCB, Kleinschmidt JH, Palazzo Jr R, Silva-Filho MC, "DNA sequences generated by $\mathbb{Z}_{4}$-linear codes,"IEEE Intl. Symp. on Inform. Theory, ISIT2010, pp. 1320-1324, 2010.

[4] Faria LCB, Rocha ASL, Kleinschmidt JH, Palazzo Jr R, Silva-Filho MC, "DNA Sequences Generated by BCH Codes over GF(4),"Electronics Letters, vol. 46, pp. 202-203, 2010.

[5] Faria LCB, Rocha ASL, Kleinschmidt JH, Silva-Filho MC, Bim E, Herai RH, Yamagishi MEB, Palazzo Jr R, "Is a Genome a Codeword of an Error-Correcting Code?,'Plos ONE, vol. 7, No. 5, pp. e36644, 2012.

[6] Tenengolts G, "Nonbinary codes, correcting single deletion or insertion,"IEEE Trans. Inform. Theory, vol. 30, No. 5, pp. 766-769, 1984. 